\title{
Nutritional, Health-Promoting Properties and Antioxidant Activity of Yemeni Fermented Milk (Laban) and A Laban-Pulicaria Jaubertii Mixture
}

\author{
Alsayadi Muneer MS. ${ }^{1, a, *}$, Almowallad Shamsan A. ${ }^{1, b}$, Yahya Mohammed A. ${ }^{2, c}$, Alsanea Ekram ${ }^{3, d}$, \\ Alfardi Talal $^{1, \mathrm{e}}$, Alhaidari Salah ${ }^{1, \mathrm{f}}$, Alhaidari Hassan ${ }^{1, \mathrm{~g}}$, Alzhri Abdullah ${ }^{1, \mathrm{~h}}$ \\ ${ }^{I}$ Department of food Science and Technology. Faculty of Agriculture and Food Science. Ibb University -.P.O. Pox 70270. Ibb-Yemen \\ ${ }^{2}$ Department of Food Science and Nutrition, College of Food and Agriculture Science, King Saud University \\ ${ }^{3}$ Department of Biology-Ibb University- Ibb-Yemen
}

*Corresponding author

A R T I C L E I N F O A B S T R A C T

Research Article

Fermented milk is known as a major functional food that has proven health benefits, such as probiotic effects. The fermented milk, laban, is the foremost dairy product in Yemen. This study aimed to evaluate the nutritional and health-promoting properties and antioxidant activity of laban. Nutritional and health-promoting properties were estimated. Antioxidant activity was evaluated by measuring total polyphenol levels, 1.1-diphenyl-2-picrylhydrazyl scavenging activity, reducing power, and total antioxidant capacity. The antioxidant activity of a laban-Pulicaria jaubertii mixture was also determined. Results showed considerable quantities of nutrients, especially fats, in both milk and laban. The composition differences between milk and laban show several significant health-promoting properties for laban. Laban showed higher antioxidant activity than raw milk and

Received : 09/03/2020

Accepted : 10/08/2020 the addition of $P$. jaubertii to the laban, increased antioxidant activity. The properties of laban

Keywords: suggested the potential use of laban as a promising functional food with excellent health benefits, Antioxidant Fermented milk especially when mixed with P. jaubertii.

Health benefits

Pulicaria jaubertii

Yemeni laban
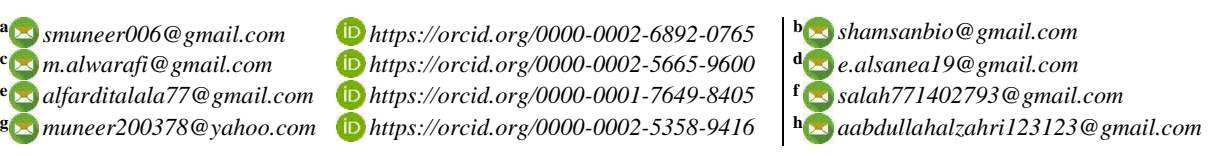

(D) https://orcid.org/0000-0002-2341-3807

\section{Introduction}

Metchnikoff and Tissier were the first to suggest the probiotic use of bacteria, even though the word "probiotic" was not coined until 1960, to refer to substances produced by microorganisms that promote the growth of other microorganisms (Lilly and Stillwell, 1965). Schrezenmeir and de Vrese (2001) defined a probiotic as "a preparation of a product containing viable, defined microorganisms in sufficient numbers, which alter the microflora (by implantation or colonization) in a compartment of the host and by that, exert beneficial health effects in this host." The Joint FAO/WHO Expert Committee on Food Additives defined probiotics as "live microorganisms which, when consumed in adequate amounts as part of food (water is included as a food), confer a health benefit on the host" (FAO/WHO, 2006).

Probiotic microorganisms are often incorporated in food products in the form of yoghurt and yoghurt-like fermented foods. Recently, probiotic ice cream, cheese, infant formula, breakfast cereals, sausages, luncheon meats, chocolate, and puddings have all been reported (Pyar and Peh, 2014). In investigations of commercial fermented milk products or probiotic dairy products available in the Western European market, the isolates (with a strain isolation step applied) have been classified as one or two Lactobacillus species and one Bifidobacterium species (Gueimonde et al., 2004). The majority of reports have suggested potential benefits following the consumption of fermented dairy products containing viable lactic acid bacteria (LAB; Gilliland, 1990; Fujiwara et al., 1997; Gill and Guarner, 2004).

Traditional fermented milk products are widely consumed globally. Several of these traditional products have been industrially manufactured using selected bacterial strains and a standardized process. Laban is a fermented milk product traditionally prepared from cow's milk in Tunisia and other Arab countries (Samet-Bali et al., 2012). 
In Tunisia, traditional laban (TL) is produced by the spontaneous fermentation of cow's milk with natural microflora. The fermentation is allowed to proceed for a period of up to $18 \mathrm{~h}$, after which the resulting fermented milk, known as "rayeb," is churned. Traditionally, churning takes place in a goat leather bag known as a "checoua" (Figure 1). Churning is achieved by hanging the "checoua" filled with "rayeb" and vigorously shaking it back and forth until the fat globules coalesce (Samet-Bali et al., 2012). The microflora of traditional Omani laban consists predominantly of mesophilic Lactococcus and homofermentative lactobacilli $\left(1.3 \times 10^{8}\right.$ and $2.4 \times 10^{6}$ $\mathrm{cfu} / \mathrm{mL}$, respectively), but also contains high numbers of yeast, coliforms, and fecal coliforms (Guizani and AlRamadani, 1999). In Egypt, investigation of laban rayeb revealed a high level of enteric bacterial contaminants, with Enterococcus as the predominant species (Khalafalla et al., 1988). Laban is the most popular traditional product in North Africa and the Middle East. The chemical and microbiological properties of traditional laban have been investigated, in an effort to standardize the product (Tantaoui-Elaraki et al., 1983; Guizani et al., 2001; Benkerroum and Tamine, 2004).

The genus, Pulicaria, is an annual herb producing small bright yellow flowers. It belongs to the Asteraceae family (tribe Inuleae, subtribe Inulinae), and includes more than 77 species widespread throughout the world (Ezoubeiri et al., 2005; Al-Hajj et al., 2014). P. jaubertii is indigenous to Yemen and is locally known as "anssif." It is traditionally used as a diuretic and an antipyretic. The flowers of $P$. jaubertii are also used as a spice in food preparation (Dubaie and El-Khulaidi, 2005). $P$. jaubertii, also known as "alkhaoah" in some regions in Yemen, is added to laban to give it distinct organoleptic properties and additional health benefits.

In Yemen, laban is the main traditional fermented milk. It is mainly produced from cow's milk, but can also be made from the milk of sheep, goats, and camels. The production process involves incubation with a traditional starter culture at ambient temperature in Yemen $\left(20-35^{\circ} \mathrm{C}\right)$ for $8-14 \mathrm{~h}$ in gourds and then separation of the milk fat by a manual churning process. The resulting liquid fermented milk (i.e., laban) is consumed directly.

Laban is widely consumed in Yemen, and it has been suggested to provide important health benefits. The longterm stability of laban without any preservation methods, suggests that it has antimicrobial activities against a wide range of microorganisms. The aim of this study was to investigate the nutritional and health-promoting Properties and antioxidant activity of laban alone and laban mixed with $P$. jaubertii.

\section{Materials and Methods}

\section{Sample Coection and Preparation}

\section{Milk and Aban}

Fresh milk and laban samples were collected from a private farm in Mafrag Hobaish Directorate, Ibb Province, Yemen. The samples were collected from May-July 2019. Each fresh milk and laban sample was collected from the same source, before and after the fermentation process. Samples were transported and stored in sterilized polyethylene bottles at $4^{\circ} \mathrm{C}$ until analysis.
To prepare for antioxidant activity assays, 100-mL samples of fresh milk and laban were adjusted to $\mathrm{pH} 4.0$ using trichloroacetic acid. The mixture was then incubated in a water bath at $60^{\circ} \mathrm{C}$ for $10 \mathrm{~min}$. The supernatant was collected and its $\mathrm{pH}$ was adjusted to 7.0 using $0.5 \mathrm{M} \mathrm{NaOH}$, and stored at $4^{\circ} \mathrm{C}$ until use.

\section{Plant Material}

P. jaubertii samples were collected in June 2019 from Bait Al Haidri Village, Al Radhmah Directorate, Ibb Province, Yemen. P. jaubertii extracts were prepared by drying the plant, milling it, and storing in polyethylene sacs. One gram of powder was mixed with $40 \mathrm{~mL}$ of ethanol:distilled $\mathrm{H}_{2} \mathrm{O}(1: 1)$. The mixture of laban and $P$. jaubertii extract was then prepared by mixing them in equal volumes $(1: 1, \mathrm{v} / \mathrm{v})$.

\section{Determination of Nutritional and Health-Promoting} Properties of Laban

The Nutritional and Health-promoting Properties of fresh milk and laban samples were determined by measuring cholesterol assimilation and the changes in milk composition by fermentation such as vitamin $\mathrm{C}$ and organic Acids production and the modification on proteins, fats, and sugars to produce polysaccharides, amino acids, and fatty acids. These properties were determined by measuring the concentration of various chemical compounds and assessing physical properties, as described below.

\section{Cholesterol Determination}

Lipid extracts from milk and laban was prepared using the Folch method. Briefly, $5 \mathrm{~mL}$ of milk was mixed with 50 $\mathrm{mL}$ of chloroform-methanol solvent $(2: 1, \mathrm{v} / \mathrm{v})$ and the lipid extract was washed with $20 \%$ of its volume of distilled $\mathrm{H}_{2} \mathrm{O}$. One milliliter of the tested solution was added to $1 \mathrm{~mL}$ of $33 \% \mathrm{w} / \mathrm{v}$ potassium hydroxide and $2 \mathrm{~mL}$ of absolute ethanol. Samples were mixed for $1 \mathrm{~min}$ and incubated at $37^{\circ} \mathrm{C}$ for 15 min. After cooling, $3 \mathrm{~mL}$ of the hexane layer was removed and added to $2 \mathrm{~mL}$ of distilled $\mathrm{H}_{2} \mathrm{O}$ (Zurkowski et al., 1962). Cholesterol determination was performed using a method described previously (Zlatkis et al., 1953; Macintyre et al., 1954; Folch et al., 1954; Zak et al., 1957), with some modifications. Briefly, $50 \mu \mathrm{L}$ of sample was added to $3 \mathrm{~mL}$ of glacial acetic acid and $2 \mathrm{~mL}$ of ferric chloride reagent in sulfuric acid. The mixture was allowed to stand for $10 \mathrm{~min}$ at ambient temperature and then the absorbance was measured at $560 \mathrm{~nm}$ using a UV-VIS spectrophotometer. Cholesterol concentration was calculated according the following equation:

Cholesterol conc. $\left(\frac{\mathrm{mg}}{\mathrm{dL}}\right)=\frac{\mathrm{A} 560_{\text {sample }}}{\mathrm{A} 560_{\text {standart }}} \times$ standard conc. $\left(200 \frac{\mathrm{mg}}{\mathrm{dL}}\right)$

\section{Protein Determination}

The concentration of protein in fresh milk and laban samples was determined by the biuret method (Weaver et al., 2005). One milliliter of milk sample $(0.1 \mathrm{~mL} / 100 \mathrm{~mL}$ distilled $\mathrm{H}_{2} \mathrm{O}$ ) and $1 \mathrm{~mL}$ of protein standard solution was added to $4 \mathrm{~mL}$ of biuret solution, mixed, and allowed to stand for $30 \mathrm{~min}$ at room temperature. Absorbance was then recorded at $550 \mathrm{~nm}$ against a distilled $\mathrm{H}_{2} \mathrm{O}$ blank using 
a UV-VIS spectrophotometer. Protein concentration was calculated according to the following equation:

$$
\text { protein conc. }\left(\frac{\mathrm{mg}}{\mathrm{dL}}\right)=\frac{\mathrm{A} 550_{\text {sample }}}{\mathrm{A} 550_{\text {standart }}} \times \text { standart conc. }(250 \mathrm{mg} / \mathrm{dL}) \text {. }
$$

\section{Determination of Sugar Content}

The sugar content of fresh milk and laban samples was determined by the phenol-sulfuric acid method (Harshal et al., 2011). In brief, $1 \mathrm{~mL}$ of $5 \%$ phenol solution was added to $1 \mathrm{~mL}$ of sample, after which $5 \mathrm{~mL}$ of concentrated $\mathrm{H}_{2} \mathrm{SO}_{4}$ was added. After $10 \mathrm{~min}$, the absorbance was measured at $488 \mathrm{~nm}$ against a blank using a UV-VIS spectrophotometer. Sugar content was expressed as glucose. Sugar concentration was calculated by the following equation:

$$
\text { sugar conc. }(\%)=\frac{\mathrm{A} 488_{\text {sample }}}{\mathrm{A} 488_{\text {standard }}} \times \text { standard conc. }
$$

\section{Determination of Fat Content, Acidity, and Specific Gravity}

The fat concentration, total titratable acidity (as lactic acid, TTA), and specific gravity of fresh milk and laban samples were measured according to the AOAC methods for milk and milk products (AOAC, 1999). The TTA (\% lactic acid equivalent) was calculated as follows:

$$
\mathrm{TTA}=[\mathrm{V}(\mathrm{NaOH}) \times \mathrm{N}(\mathrm{NaOH}) \times 0: 009] / \mathrm{W}_{\text {sample }} \times 100
$$

$$
\begin{aligned}
& \text { Where; } \\
& \mathrm{V}=\text { Is the volume of } \mathrm{NaOH} \\
& \mathrm{N}=\text { Is the normality of } \mathrm{NaOH} \\
& \mathrm{W}=\text { Is weight of sample }
\end{aligned}
$$

\section{Vitamin $C$ determination}

Vitamin $\mathrm{C}$ was measured in milk samples using the $\mathrm{N}$ Bromo succinimide method (Aldalaly and Alhakim, 1987; Shehab and Hassan, 1978).

\section{Antioxidant Activity Determination}

\section{Total Phenolic Content Assay}

Total phenolic content was determined as described by Shetty et al. (1995). Briefly, $1 \mathrm{~mL}$ of water extract from fresh milk or laban samples transferred to a test tube and mixed with $1 \mathrm{~mL}$ of $95 \%$ ethanol and $5 \mathrm{ml}$ of distilled $\mathrm{H}_{2} \mathrm{O}$. Then, $0.5 \mathrm{~mL}$ of $50 \%$ (v/v) Folin-Ciocalteu reagent was added to each sample, followed by a thorough mixing. After 5 min, $1 \mathrm{~mL}$ of $5 \% \mathrm{Na}_{2} \mathrm{CO}_{3}$ was added and the reaction mixture was allowed to stand for $60 \mathrm{~min}$. Absorbance was measured at $725 \mathrm{~nm}$ using a UV-VIS spectrophotometer. Standard curves were established using various concentrations of gallic acid $(5-60 \mu \mathrm{g} / \mathrm{mL})$ in methanol and were used to convert absorbance values to total phenolic content, expressed in microgram equivalents of gallic acid per gram ( $\mu \mathrm{g}$ GAE/g) of sample.

Measurement of Free Radical Scavenging Activity

The free radical scavenging activity (antioxidant capacity) of sample extracts towards the stable radical 1,1diphenyl-2-picrylhydrazyl (DPPH), was evaluated by the method reported by Unal et al., (2013), with some modifications. In this assay, $1 \mathrm{~mL}$ of a sample extract solution at different concentrations $(20,40,60,80$, and 100 $\mu \mathrm{g} / \mathrm{mL}$ in methanol) was mixed with $1 \mathrm{~mL}$ of a DPPH solution $(200 \mathrm{mg} / \mathrm{mL}$ in methanol). Solution containing an equal amount of methanol and DPPH, without added sample, served as a control. After $30 \mathrm{~min}$ at room temperature in the dark, absorbance was measured at 517 $\mathrm{nm}$ against a methanol blank using a UV-VIS spectrophotometer, as described above. The percentage free radical scavenging activity was calculated according to the following equation:

scavenging activity $(\%)=[($ Ac-As $) /$ Ac $] \times 100$

Where;

Ac $=$ Is the absorbance of control

As $=$ Is the absorbance of the sample

\section{Total Antioxidant Capacity}

The total antioxidant capacity of the extracts was evaluated by the phosphomolybdenum method, according to the procedure described by Prieto et al. (2004). A $0.3-$ $\mathrm{mL}$ aliquot of sample extract at various concentrations (20, $40,60,80$, and $100 \mu \mathrm{g} / \mathrm{mL}$ ) was combined with $3 \mathrm{~mL}$ of reagent solution $(0.6 \mathrm{M}$ sulfuric acid, $28 \mathrm{mM}$ sodium phosphate, and $4 \mathrm{mM}$ ammonium molybdate). The tubes containing the reaction solution were incubated at $95^{\circ} \mathrm{C}$ for $90 \mathrm{~min}$. After cooling to room temperature, the absorbance of the solution was measured at $695 \mathrm{~nm}$ against a methanol blank, using a UV-VIS spectrophotometer. Total antioxidant activity was expressed as the number of gram equivalents of tannic acid. A calibration curve was prepared by mixing tannic acid with distilled $\mathrm{H}_{2} \mathrm{O}$ to concentrations of $20,40,60,80$, and $100 \mu \mathrm{g} / \mathrm{mL}$. All these experiments were performed in triplicate.

\section{Reducing Power Assay}

The total reducing power of each extract was determined according to a previously described method (Aliyu et al., 2013). Equal volumes (2.5 mL) of different concentrations of the sample extracts $(20,40,60,80$, and $100 \mu \mathrm{g} / \mathrm{mL})$, phosphate buffer solution (0.2 M, pH 6.6), and $1 \%$ potassium ferricyanide $\left[\mathrm{K}_{3} \mathrm{Fe}(\mathrm{CN})_{6}\right]$ were added to test tubes. The mixture was placed in a water bath at $50^{\circ} \mathrm{C}$ for $20 \mathrm{~min}$. Then, $2.5 \mathrm{~mL}$ of $10 \%$ trichloroacetic acid was added and the solution was mixed thoroughly. A $2.5-\mathrm{mL}$ aliquot of this mixture was then added to $2.5 \mathrm{~mL}$ of distilled $\mathrm{H}_{2} \mathrm{O}$ and $0.5 \mathrm{~mL}$ of $0.1 \% \mathrm{FeCl}_{3}$ and the solution was allowed to stand for $10 \mathrm{~min}$. The absorbance of this mixture was then measured at $700 \mathrm{~nm}$ using a UV-VIS spectrophotometer. A higher absorbance value of the reaction mixture indicated greater reducing power. Ascorbic acid was used as a positive control. All these experiments were performed in triplicate.

\section{Statistical Analysis}

Means and standard deviations (SD) were calculated and data were analysed by one-way ANOVA. Duncan's Multiple Range test was used to determine whether differences were significant, as indicated by $\mathrm{P} \leq 0.05$. Statistical analyses were performed using the SPSS V21 software package (SPSS Inc., Chicago, IL, USA). 


\section{Results and Discussion}

\section{Nutritional and Health-Promoting Properties}

The Nutritional and Health-promoting Properties of laban were determined by comparing its physical and chemical properties with those of fresh milk. In addition, changes in milk structure due to microorganisms during the fermentation process were also investigated. Figure 1 illustrates the Nutritional and Health-promoting Properties of laban. During laban production, cholesterol assimilation was $16.67 \%$. Lactic acid content increased by $55.22 \%$ (w/v), protein content decreased by $22.76 \%$, and vitamin C increased $12.6 \%$. In addition, sugar and fat content were 11.5 and $12 \%$ lower, respectively, in laban than in fresh milk. Statistical analysis showed that laban surpassed milk for all tested Nutritional and Health-promoting Properties.

Probiotics are available in many different forms. They are components of foods, usually fermented foods, including those prepared by traditional methods and are also in pharmaceutic products, mainly as capsules or in microencapsulated form. By definition, probiotic strains may even be undefined organisms from fermented foods, that survive passage through the gut and exert positive effects in the gastrointestinal tract (Goktepe et al., 2006). The ideal properties of a probiotic include proven safety in clinical trials and/or a long history of use in foods (Michail and Philip, 2009). Figure 1. Nutritional and Healthpromoting Properties of laban.

LABs in milk have been shown to possess proteolytic enzymes, such as proteinases, peptidases, and aminopeptidases at extracellular and intracellular levels (Osaana et al., 2007). Bioactive peptides can be liberated from milk proteins by enzymatic hydrolysis with digestive enzymes or by the fermentation of milk using proteolytic starter cultures and the subsequent action of enzymes derived from these microorganisms. After these peptides are releasing during food processing, they may exert various physiological effects (Sarmadi and Ismail, 2010). The decrease in protein content in laban compared with fresh milk in this experiment indicated that some of the proteins had converted into peptides and amino acids by the actions of bacteria during the fermentation process. This may be due to the proteolytic activity of the laban starter culture, since the protein profile of milk has been shown to change with all starters used. The greatest amount of proteolysis is observed when both Lactobacillus delbrueckii subsp. bulgaricus 286 and 287 are used as costarters (Aleksandrova et al., 2013). The proteolytic activities of LAB, including yoghurt starter bacteria and probiotic organisms, have been studied extensively and their proteolytic enzymes have been isolated and characterized (Wohlrab and Bockelmann, 1992; Shihata and Shah, 2000). Biologically active peptides are generated during milk fermentation by proteolytic enzymes produced by various species of $\mathrm{LAB}$, such as L. helveticus, $L$. lactis subsp. Cremoris FT4, and L. delbrueckii ssp. Bulgaricus SS1 (Gobbetti et al., 2002). These biologically active peptides include hypotensive peptides that inhibit angiotensin I-converting enzyme; opioid agonist and antagonist peptides; and mineral binding, immunomodulatory, antibacterial, and antithrombotic peptides (Shah, 2000; Pihlanto and Korhonen, 2003).

The high acid content of laban seen in this study is likely due to the production of lactic acid, amino acids, and fatty acids from sugar, proteins, and lipids, respectively. That was confirmed by the finding that sugar and fat content decreased during laban production.

Fermentation in food processing involves the conversion of carbohydrates to alcohol and carbon dioxide or organic acids by bacteria (William, 2011). The organisms most commonly used for the fermentation of foods are acid-forming bacteria, such as the LAB genera, Lactobacillus, Lactococcus, Leuconostoc, Enterococcus, Streptococcus, Aerococcus, and Pediococcus (Chelule et al., 2010). Lactic acid fermentation of food has been found to reduce the risk of contamination with pathogenic microorganisms (Abdel et al., 2009).

The main species of microorganisms that can potentially be used as probiotic cultures in dairy products include, Lb. acidophilus and/or Lb. johnsonii, $L b$. delbrueckii subsp. bulgaricus, Lb. delbrueckii subsp. lactis, Lb. casei, Lb. gasseri, Lb. helveticus, B. breve, E. faecalis, E. faecium, and P. acidilactici (Tamime, 2005).

Cholesterol assimilation was observed during the milk fermentation process in this study. There is some data reported in the literature suggesting that $\mathrm{LAB}$ can reduce the quantity of cholesterol during the production of fermented dairy beverages. Some of the putative health benefits of probiotics include a reduction in total cholesterol and the assimilation of cholesterol is one of the proposed mechanisms (Gibson and Beaumont, 1996).

Juskiewicz and Panfil-Kuncewicz (2003) showed that bacteria included in thermophilic starter cultures possess the ability to reduce cholesterol content in milk during its fermentation. In that study, cholesterol assimilation by a classic yoghurt starter culture was $22.2 \%$ and $19.8 \%$ in yoghurt containing $4 \%$ and $8 \%$ fat, respectively. This exceeded the degree of cholesterol assimilation seen in laban in this study. However, another study used another yoghurt starter culture with a similar qualitative composition, showed cholesterol assimilation abilities of $11.3 \%$ and $15.4 \%$ in yoghurt containing $4 \%$ and $8 \%$ fat, respectively. In agreement with this study, another study found that Pediococcus plantarum L14/1, P. acidilactici L25, Lb. plantarum L26, Lb. pentosus, and E. faecium N15 were able to remove $15-17 \%$ of cholesterol from the culture medium without bile acid (Monthon et al., 2014). In starter cultures used for the production of traditional yoghurt, consisting of Streptococcus salivarius subsp. thermophilus, and Lactobacillus delbrueckii subsp. bulgaricus, the quantity of assimilated cholesterol did not exceed $27 \%$ of its initial content $\left(0.7 \mathrm{~g}\right.$ in $1 \mathrm{dm}^{3}$; Ziarno, 2007). LAB from a commercial yoghurt culture was shown to bind $111 \mu \mathrm{g}$ of cholesterol in $1 \mathrm{~cm}^{3}$ of MRS broth medium during $18 \mathrm{~h}$ of incubation at $37^{\circ} \mathrm{C}$. The $\mathrm{Lb}$. delbrueckii subsp. bulgaricus strain showed the highest assimilation ability among all the cultures tested in that study. It was able to bind $276 \mu \mathrm{g}$ of cholesterol in $1 \mathrm{~cm}^{3}$ of medium (Rasic et al., 1992).

\section{Chemical and Physical Properties of Milk Products}

In general, cow's milk is mainly composed of water, with approximately $4.8 \%$ lactose, $3.2 \%$ protein, $3.7 \%$ fat, $0.19 \%$ nonprotein nitrogen, and $0.7 \%$ ash (Banks and Dalgleish, 1990; Fox and McSweeney, 2006). The results of our physicochemical analyses of fresh milk and laban are presented below 


\section{Total Acidity}

The results presented in Figure 2 show the total acidity, measured as lactic acid, for fresh milk and laban samples. It is clear from these data that lactic acid is three-fold higher in laban than in fresh milk and this difference was statistically significant $(\mathrm{P} \leq 0.05)$.

Figure 2. Total acidity of fresh milk and laban. Results are presented as mean \pm standard deviation, $n=3$ per group.

The increase in the acidity of laban was due to the production of lactic acid from lactose by the starter culture, as indicated by the decrease in the sugar content of laban and the reduction of proteins to amino acids and fats to fatty acids and glycerol. The titratable acidity of laban in this study was lower than that of yoghurt and probiotic yoghurt, which have been reported as $0.96 \%$ and $1.04 \%$, respectively (Yangilar and Çakmakci, 2017).

\section{Protein Content}

Figure 3 shows the protein concentration of fresh milk and laban. The protein concentration of fresh milk (4.13\%) was higher than that of laban $(3.19 \%)$. The protein content of laban observed in this study was lower than that reported for yoghurt and probiotic yoghurt, which are 3.80\% and $3.76 \%$, respectively (Yangilar and Çakmakci, 2017).

Figure 3. Protein content of fresh milk and laban. Results are presented as mean \pm standard deviation, $\mathrm{n}=3$.

Milk proteins are regarded as a source of energy and essential amino acids, which are needed for growth and the maintenance of physiological functions (Sarmadi and Ismail, 2010). Our results agree with that of a previous study showing that the concentration of protein in fresh and fermented buffalo milk is $0.817 \mathrm{mg} / \mathrm{mL}$ and $0.501 \mathrm{mg} / \mathrm{mL}$, respectively and peptide concentrations are $0.4 \mathrm{mg} / \mathrm{mL}$ and $0.805 \mathrm{mg} / \mathrm{mL}$ before and after fermentation, respectively (Hussein et al., 2015).

\section{Fat Content}

Fresh milk samples in this study were shown to have higher quantities of fat compounds than laban (Figure 4).
These differences between the two milk products were statistically significant $(\mathrm{P} \leq 0.05)$.

Figure 4. Fat content of fresh milk and laban. Results are presented as mean \pm standard deviation, $\mathrm{n}=3$.

Fat content observed in laban in the present study was higher than the fat content of yoghurt and probiotic yoghurt, reported to be $3.40 \%$ and $3.50 \%$, respectively (Yangilar and Çakmakci, 2017). This difference is attributed to the higher fat content in the fresh milk samples prior to fermentation in our study.

\section{Vitamin C Content}

Figure 5 shows the concentration of vitamin $\mathrm{C}$ in fresh milk and laban samples. The mean vitamin $\mathrm{C}$ concentration in laban samples was $4.2 \mathrm{mg} / 100 \mathrm{~mL}$, which was higher than the concentration in fresh milk samples $(3.7 \mathrm{mg} / 100$ $\mathrm{mL})$.

Figure 5. Vitamin $\mathrm{C}$ content of fresh milk and laban. Results are presented as mean \pm standard deviation, $\mathrm{n}=3$.

Vitamin $\mathrm{C}$ acts as an oxygen scavenger. Milk and milk products supply only 10-15\% of the daily requirements of vitamin C (Rasic and Kurmann, 1978). In addition to vitamin $\mathrm{C}$, milk also contains other water-soluble vitamins, such as B vitamins, in variable quantities (Miller et al., 2000). Andersson and Oste (1994) reported that vitamin C concentrations in unpasteurized milk are highest in March and August (20-27 mg/L) and lowest in October (12 $\mathrm{mg} / \mathrm{L}$ ). The mean content of vitamin $\mathrm{C}$ in cow's milk is $2.11 \mathrm{mg} / 100 \mathrm{~g}$ (range 1.65-2.75 mg/100 g; Walstra and Jenness, 1984). This is lower than that in the Yemeni milk used in this study. The vitamin $\mathrm{C}$ content of laban in this study was also higher than that of fermented milk products produced using a kombucha starter and fermented on sweetened wild thyme extract, which was 12.36-31.19 $\mathrm{mg} / \mathrm{L}$ (Malbaša et al., 2014).

These results indicate that the microorganisms in laban possess a robust ability to produce vitamin $\mathrm{C}$ in fermented milk, which enhances the nutritional value and bioactivity of these products.

Health-promoting properties of laban

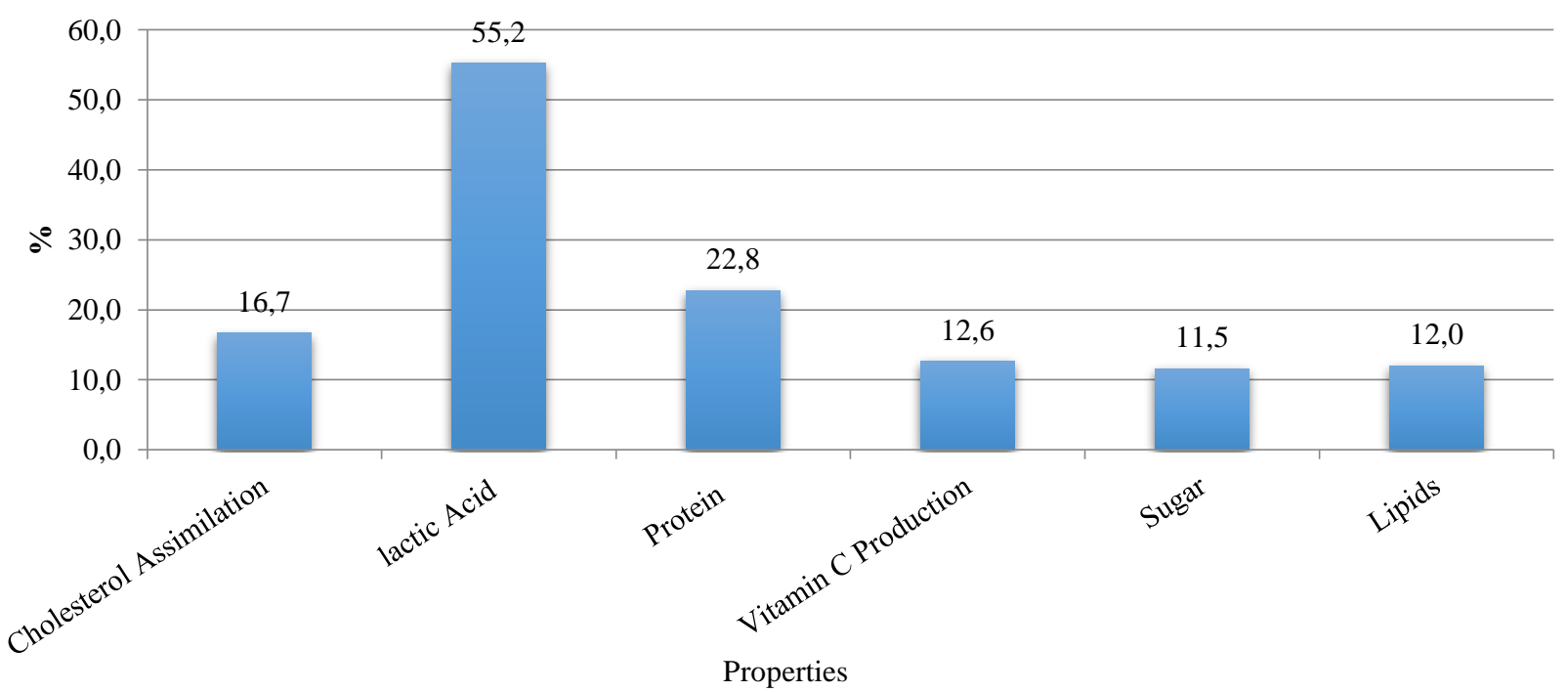

Figure 1. Nutritional and Health-promoting Properties of laban. 


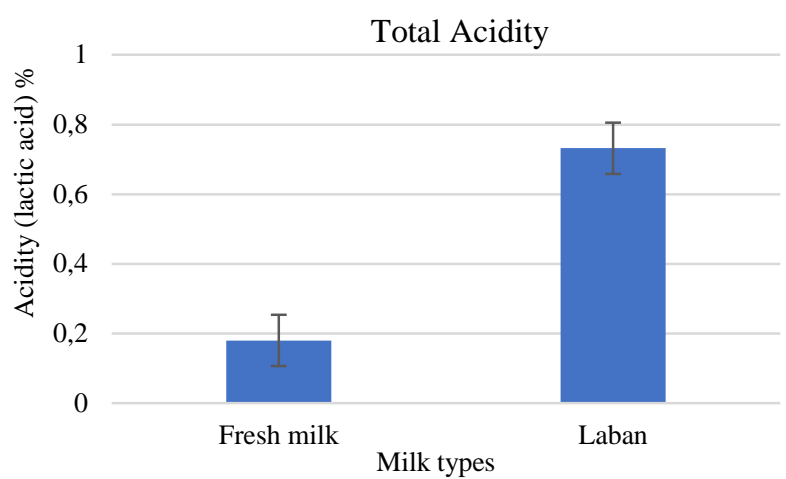

Figure 2. Total acidity of fresh

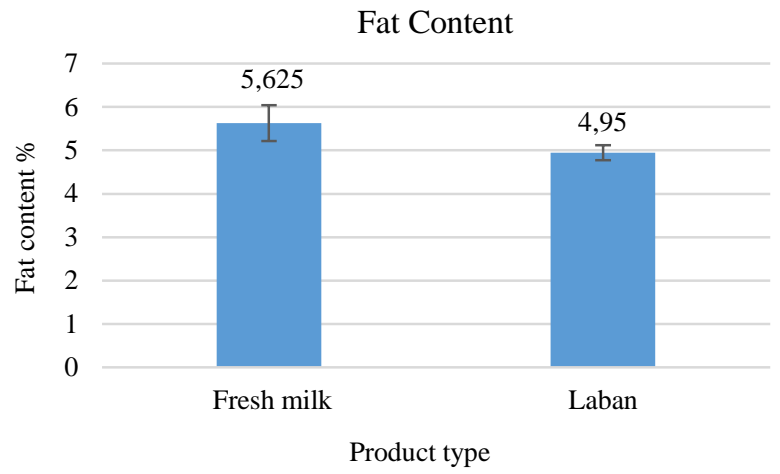

Figure 4. Fat content of fresh milk and laban.

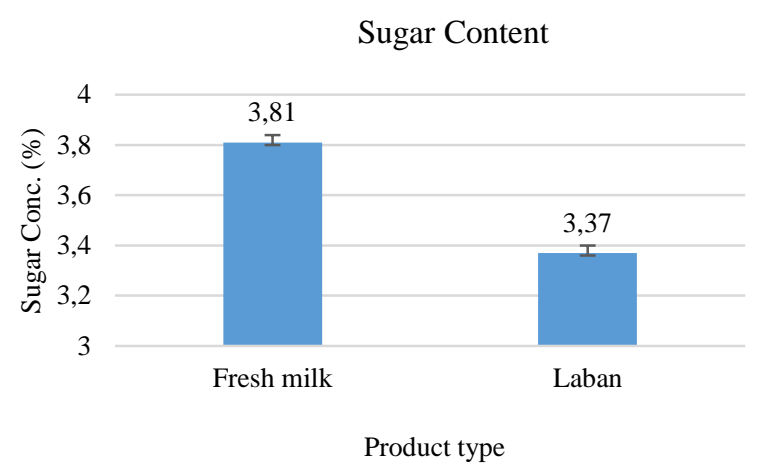

Figure 6. Sugar content of fresh milk and laban.

\section{Sugar Content}

The results presented in Figure 6 show that the sugar content of fresh milk (3.81\%) was higher than that of laban $(3.37 \%)$. Figure 6. Sugar content of fresh milk and laban. Results are expressed as mean \pm standard deviation, $\mathrm{n}=3$.

\section{Cholesterol Content}

The cholesterol content of fresh milk and laban were determined by the ferric chloride method. As shown in Figure 7, the cholesterol content of fresh milk was $58.5 \%$, but his decreased to $48.75 \%$ in laban.

Figure 7. Cholesterol content of fresh milk and laban. Results are presented as mean \pm standard deviation, $n=3$.

The normal value of cholesterol in milk is $3.3 \mathrm{mg} / \mathrm{g}$ of fat (Fox and McSweeney, 2006). Many experiments have been performed in vitro and in vivo to investigate the hypocholesterolemic effect of LAB. These studies have concluded that fermentation of dairy products with the appropriate strain(s) of bacteria may result in a decrease in the concentration of circulating cholesterol (Tamime, 2005).

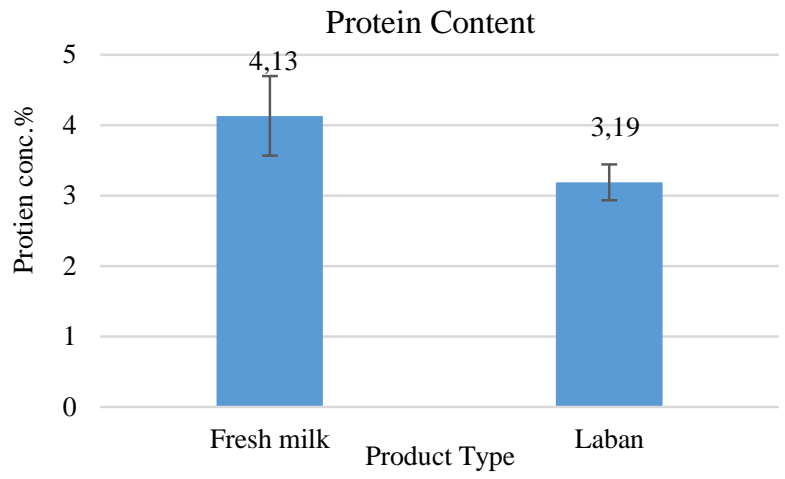

Figure 3. Protein content of fresh milk and laban.

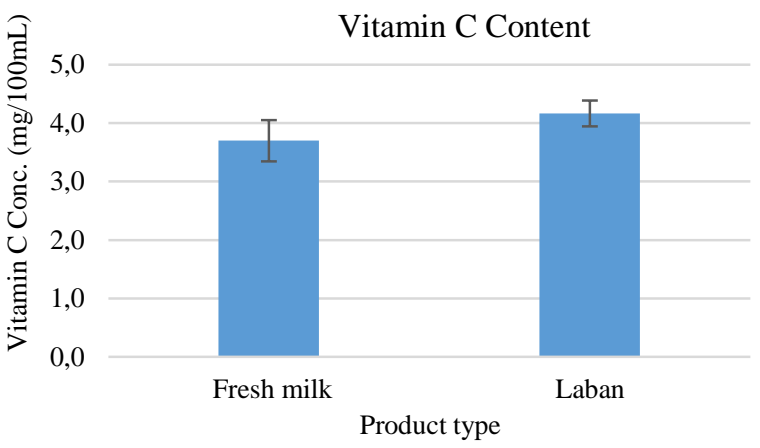

Figure 5. Vitamin C content of fresh milk and laban.

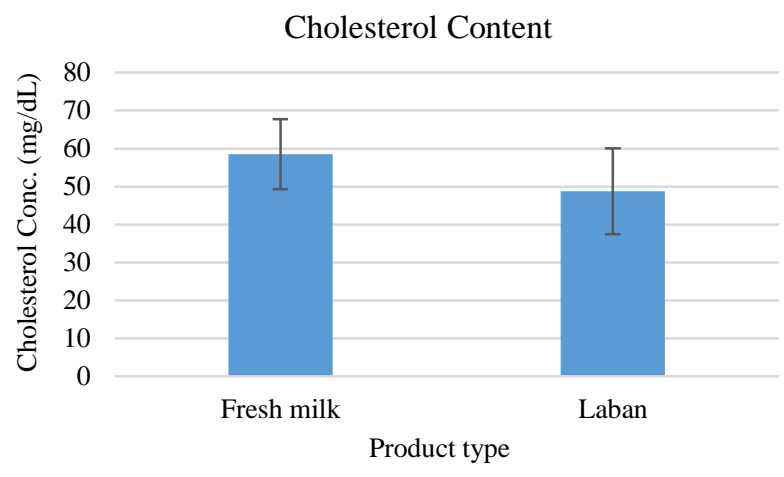

Figure 7. Cholesterol content of fresh milk and laban.

\section{Antioxidant Activity}

Total Polyphenol Content

Total polyphenol quantities were highest in the laban$P$. jaubertii mixture, followed by laban alone, and then fresh milk (Figure 8). Statistical analysis showed that the difference in polyphenol content between the laban- $P$. jaubertii mixture and the other two milk products was highly significant $(\mathrm{P} \leq 0.05)$, but there was no significant difference between fresh milk and laban.

Figure 8. Total polyphenol content of fresh milk, laban, and a laban- $P$. jaubertii mixture. The letters $\mathrm{a}, \mathrm{b}$, and $\mathrm{c}$ indicate significant differences between treatments $(\mathrm{P} \leq 0.05)$. GAE, gallic acid equivalents; L-P, laban- $P$. jaubertii mixture.

Total Antioxidant Capacity

Total antioxidant capacity of the different milk products is shown in Figure 9. The laban- $P$. jaubertii mixture showed the highest antioxidant capacity, followed by laban alone and then fresh milk. Statistical analysis showed that the difference in antioxidant capacity between 
the laban- $P$. jaubertii mixture and the other two milk products was highly significant $(\mathrm{P} \leq 0.05)$, but there was no significant difference between fresh milk and laban.

Figure 9. Total antioxidant capacity of fresh milk, laban, and a laban- $P$. jaubertii mixture. The letters $\mathrm{a}$ and $\mathrm{b}$ indicate significant differences between treatments $(\mathrm{P} \leq 0.05)$. L-P, laban- $P$. jaubertii mixture.

A previous study has shown that Bulgarian yoghurts have antioxidant probiotic properties (Aleksandrova et al., 2013). The antioxidant activity of laban, as with other fermented milk products, may be attributed to the presence of antioxidant compounds, such as proteins, peptides and amino acids, uric acid, vitamin $\mathrm{C}$ and $\mathrm{A}$, carotenoids, coenzyme Q10, and enzymes, combined with the antioxidant activity of LAB (Pihlanto, 2006; Jiménez et al., 2008; Zulueta et al., 2009).

\section{DPPH-Scavenging Activity}

The DPPH-scavenging activities of fresh milk, laban, and the laban-P. jaubertii mixture are illustrated in Figure 10. The laban- $P$. jaubertii mixture had the highest DPPH-scavenging activity, followed by laban alone, and then fresh milk.

Statistical analysis showed that the difference in DPPH-scavenging activity between the laban- $P$. jaubertii mixture and the other two milk products was significant $(\mathrm{P} \leq 0.05)$, but there was no significant difference between fresh milk and laban. DPPH-scavenging activity of fresh milk, laban, and a laban- $P$. jaubertii mixture. The letters a, $\mathrm{b}$, and $\mathrm{c}$ indicate significant differences between treatments $(\mathrm{P} \leq 0.05)$. L-P, laban- $P$. jaubertii mixture.

A previous study has shown that TAC levels are in the range of 13.33 to $25.93 \mathrm{mg}$ TE per $100 \mathrm{~mL}$ of human milk, when using the ABTS method and 2.45 to $17.66 \mathrm{mg}$ TE per $100 \mathrm{~mL}$, when using the DPPH test (Dorota and Weronika, 2012). The highest DPPH-radical-scavenging ability was found for yoghurts $(0.19 \mathrm{mM} \mathrm{TE} / \mathrm{kg})$ and kefirs $(0.17 \mathrm{mM}$ $\mathrm{TE} / \mathrm{kg}$ ), followed by buttermilk, cultured milks, and ayran (Najgebauer-Lejko and Sady, 2015). However, kombuchafermented milk products containing wild thyme showed different antioxidant responses to DPPH and hydroxyl radicals, with DPPH antioxidant activity at 1.36-36.12\% and $\mathrm{OH}$ antioxidant activity at 3.11-5.12\% (Malbaša, 2014). Another study showed that probiotic yoghurt extracts possessed very high DPPH-scavenging activities, ranging from 90 to $93 \%$ (Unal et al., 2013). The high antioxidant activity of the mixture of laban and $P$. jaubertii agrees with the findings of Najgebauer-Lejko and Sady (2015), who found that flavored fermented milk products have strong antioxidant properties, which differed according to the type and quality of the product. This has also been confirmed by Al-Naqeb (2015), who found that the scavenging activity of $P$. jaubertii gradually increased to $84 \%$ of the total free radicals. The author suggested that the high antioxidant and antimicrobial activity of $P$. jaubertii makes it a potential component of new pharmacological products.

\section{Reducing Power}

Figure 11 shows the reducing power of milk, laban, and the laban-Pulicaria jaubertii mixture. The results show that the highest reducing power activity was observed in the laban-Pulicaria jaubertii mixture followed by laban and fresh milk. Reducing power of milk, laban and a laban$P$. jaubertii mixture. The letters $\mathrm{a}, \mathrm{b}$, and $\mathrm{c}$ indicate significant differences between treatments $(\mathrm{P} \leq 0.05)$.

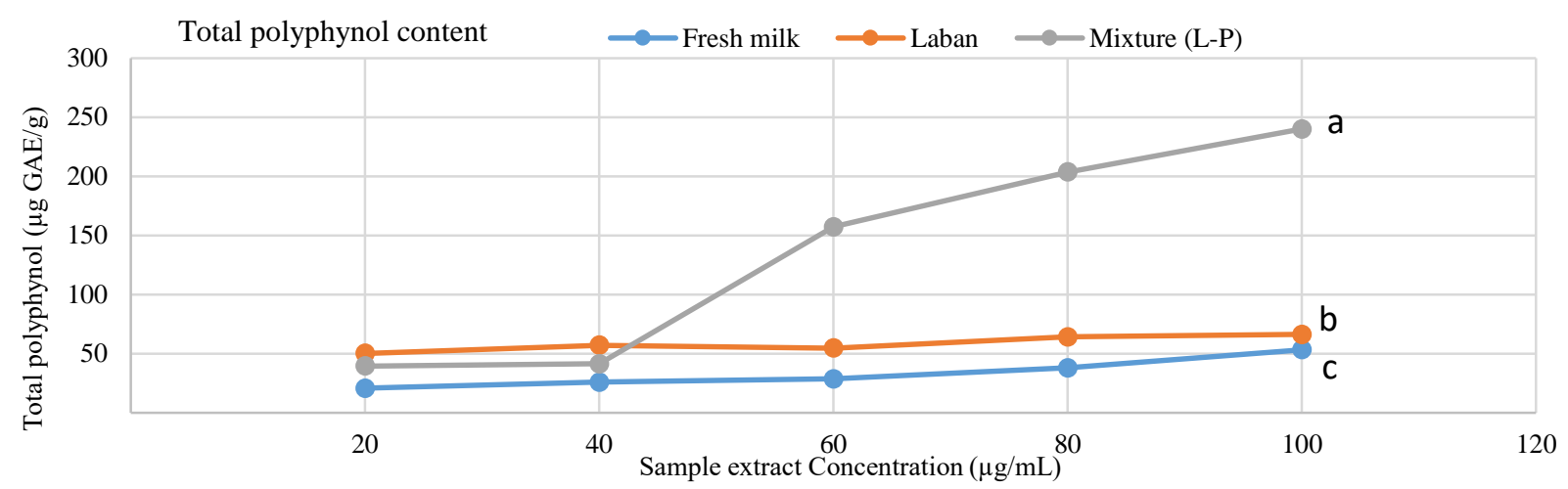

Figure 8. Total polyphenol content of fresh milk, laban, and a laban-P. jaubertii mixture

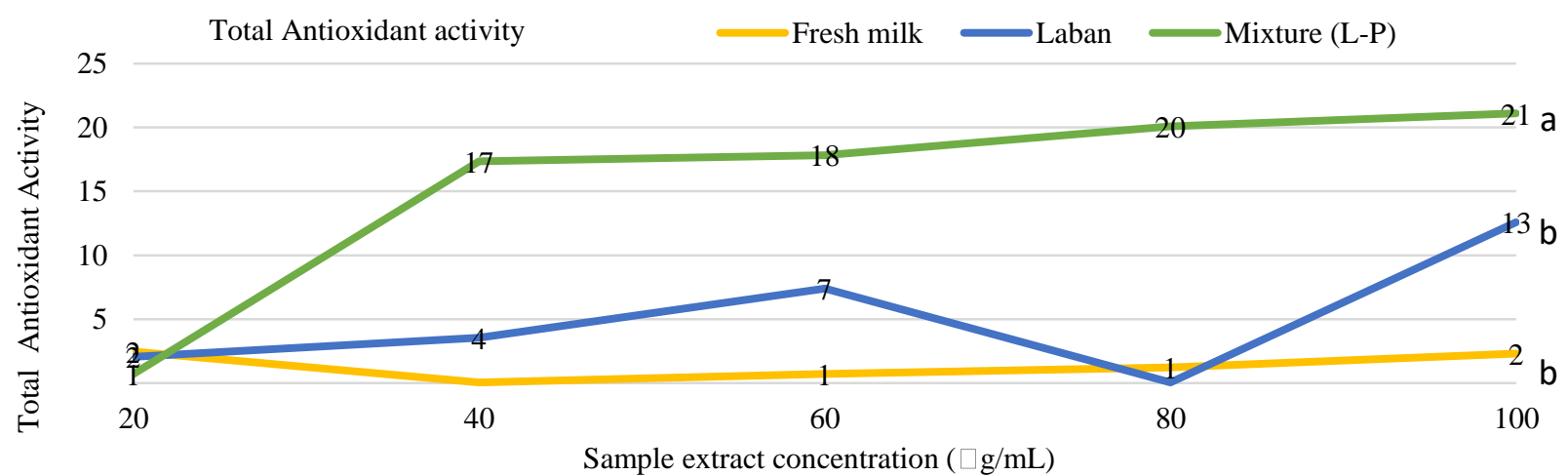

Figure 9. Total antioxidant capacity of fresh milk, laban, and a laban-P. jaubertii mixture 


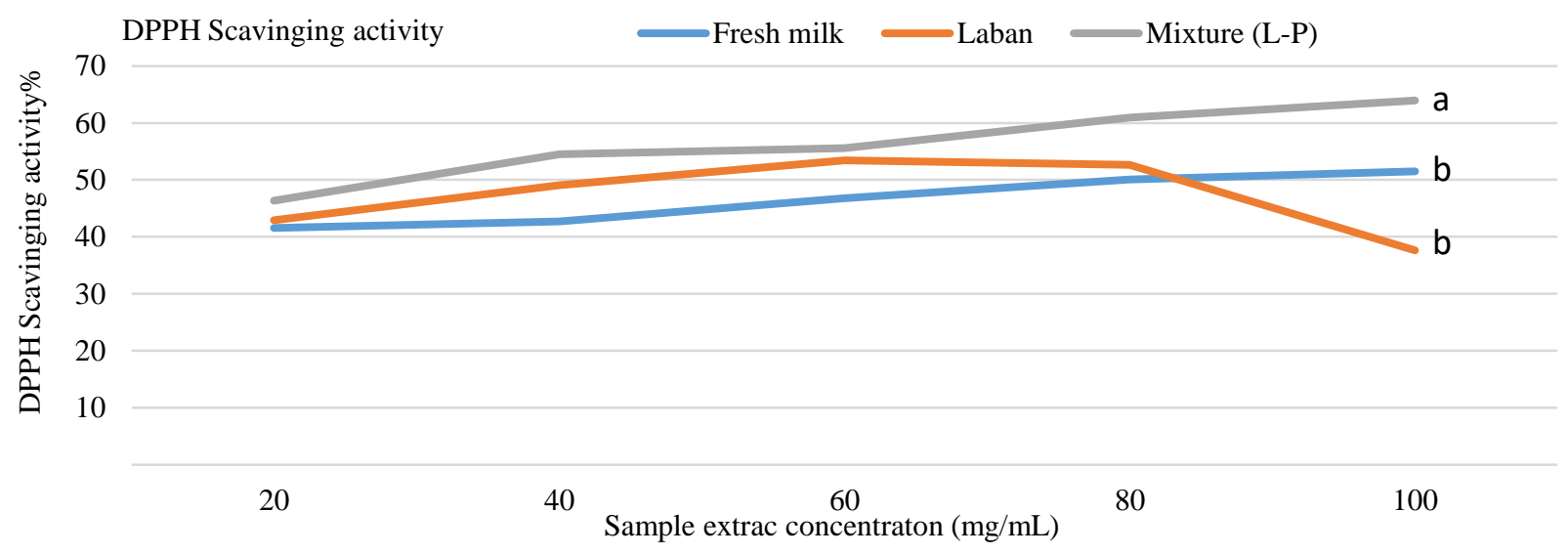

Figure 10. DPPH-scavenging activity of fresh milk, laban, and a laban-P. jaubertii mixture

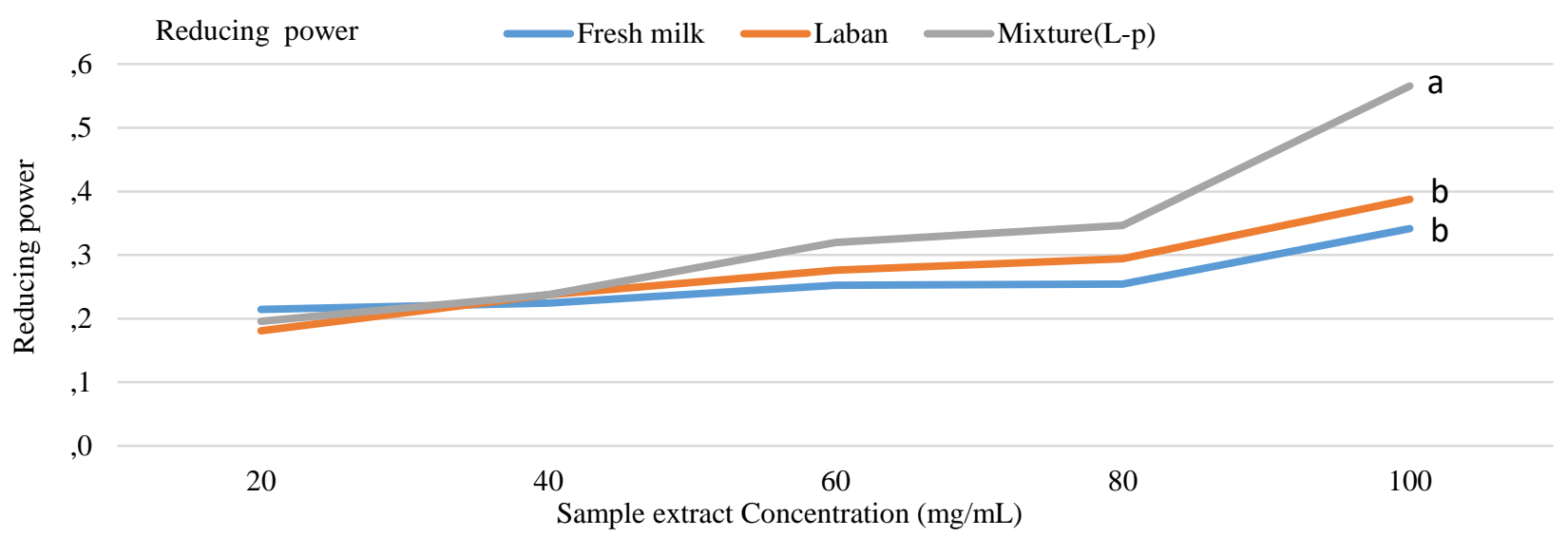

Figure 11. Reducing power of milk, laban and a laban-P. jaubertii mixture

This high scavenging ability of laban's proteins may be attributed to lactoferrin, which has been reported to be a key factor affecting scavenging activity (Shinmoto et al., 1992; Chiang and Chang, 2005). In addition, $\alpha$-lactalbumin and $\beta$-lactoglobulin (Hernandez-Ledesma et al., 2005; Del Mar Contreras et al., 2011) may also contribute to the antioxidant activity of laban. Similar to this study, plain yoghurts have been found to have the highest FRAP values of products tested (1.4-2.4 mM Fe2+/dm ${ }^{3}$ ) (NajgebauerLejko, and Sady, 2015).

\section{Conclusion}

Fresh and fermented Yemeni milk contained a high fat content and considerable quantities of vitamin $\mathrm{C}$, proteins, and sugar. Laban can considered a promising functional food, because of its ability to reducing of cholesterol, fats, proteins and sugar contents to produce polysaccharides, amino acids and peptides, fatty and organic acids, and vitamin C. Furthermore, through the traditional using history, it is stable and has favorable organoleptic properties. Fresh Yemeni milk and laban contained measurable polyphenol compounds and both products had good antioxidant activity. The fermentation process used to produce laban further enhances the antioxidant activity of the milk. $P$. jaubertii is known to have high polyphenol content and considerable antioxidant activity. Mixing laban and $P$. jaubertii gave a synergistic effect, resulting in greater antioxidant capacity. Therefore, it can be concluded that the traditional Yemeni fermented milk (Laban), possesses excellent therapeutic and nutritional potential.

\section{Acknowledgments}

The authors are grateful to the Department of Food Sciences and Technology, Faculty of Agriculture, Ibb University, Yemen, for providing facilities to enable this study.

\section{References}

Abdel AA, Dardir HA. 2009. Hygienic quality of local traditional fermented skimmed milk (Laban Rayb) sold in Egypt. World Journal of Dairy \& Food Sciences, 4(2): 205-209.

Aleksandrova V, Chikov G, Velikova G, Dimitrov M, Dimov SG. 2013. In vivo antioxidant activity evaluation of peptides produced during the fermentation of yoghourt-like dairy products. Bulgarian Journal of Agricultural Science, Supplement 2, 19: 90-100.

Al-Hajj N, Hongxin W, Chaoyang M, Zaixiang L, Mohanad B, Riyadh T. 2014. Antimicrobial and antioxidant activities of the essential oils of some aromatic medicinal plants (Pulicaria inuloides-Asteraceae and Ocimum forskolei-Lamiaceae. Tropical Journal of Pharmaceutical Research, 13(8): 1287-1293.

Abubakar AB, Ibrahim MA, Musa AM, Musa AO, Kiplimo JJ, Oyewale AO. 2013. Free radical scavenging and total antioxidant capacity of root extracts of anchomanes difformis engl. (Araceae). Acta Poloniae Pharmaceutica-Drug Research, Vol. 70 No.1 pp. 115-121.

Al-Naqeb G. 2015. Antioxidant and antibacterial activities of some Yemeni medicinal plants. International Journal of Herbal Medicine, 3(3): 06-11.

Andersson I, Oste R. 1994. Nutritional quality of pasteurized milk. Vitamin B12, folacin and ascorbic acid content during storage. International Dairy Journal, 4: 161-172. 
Banks W, Dalgleish D. 1990. Milk and milk processing in Robinson R K, Dairy Mircobiology, Volume 1, The Microbiology of Milk, second edition, London, Elsevier Science Publishers Ltd, 1-35.

Benkerroum N, Tamine AY. 2004. Technology transfer of Moroccan traditional dairy products (Lben, jben and smen) to small industrial scale. Food Microbiology, 21: 399-413.

Chelule PK, Mbongwa HP, Carries S, Gqaleni N. 2010. Lactic acid fermentation improves the quality of amahewu, a traditional South African maize-based porridge. Food Chemistry, 122(3): 656-661.

Dalaly B, Achakem SH. 1987. Food Analysis. Ministry of high education and scientific research. Al-Mosel University. AlMosel. Iraq. Pp. 563.

Del Mar Contreras M, Hernandez-Ledesma B, Amigo L, Martinelvarez PJ, Recio I. 2011. Production of antioxidant hydrolyzates from a whey protein concentrate with thermolysin: Optimization by response surface methodology. LWT-Food Science and Technology, 44: 9.

Martysiak-Żurowska D, Wenta W. 2012. A comparison of ABTS and DPPH methods for assessing the total antioxidant capacity of human milk. Acta Scientiarum Polonorum Technologia Alimentaria, 11(1): 83-89.

Dubaie AS, El-Khulaidi AA. 2005. Medicinal and aromatic plants in Yemen, deployment-components of effective-uses. Ebadi Center for studies and Publishing Sana'a-Yemen. p.127.

El SN, Karakaya S. 2004. Radical scavenging and iron chelating activities of some greens used as traditional dishes in Mediterranean diet. International Journal of Food Sciences and Nutrition, 55 (1): 67.

Ezoubeiri A, Gadhi CA, Fdil N, Benharref A, Jana M, Vanhaelen M. 2005. Isolation and antimicrobial activity of two phenolic compounds from Pulicaria odora L. Journal of Ethnopharmacology, 99: 287-292.

FAO/WHO. 2006. Probiotics in food Health and nutritional properties and guidelines for evaluation. Rome Italy, FAO and WHO. 2006.

Folch J, Lees M, Stanley GMS. 1957. A simple method for the isolation and purification of total lipids from animal tissues. Journal of Biological Chemistry, 467: 226-509.

Fox PF, McSweeney PLH. 2006. Advanced Dairy Chemistry Volume 2 Lipids. Springer ScienceBusiness Media, Inc. pp. 816

Fujiwara S, Hashiba H, Hirota T, Forstner JF. 1997. Proteinaceous factor(s) in culture supernatant fluids of Bifidobacteria which prevents the binding of enterotoxigenic Escherichia coli to gangliotetraosylceramide. Applied and Environmental Microbiology, 63: 506-512.

Gibson G, Beaumont A. 1996. An overview of human colonic bacteriology in health and disease. In A R Leeds and I R Rowland (eds), pp. 3-11, Gut Flora and Health: Past, Present and Future, International Congress and Symposium Series 219, London, Royal Society of Medicine.

Gill HS, Guarner F. 2004. Probiotics and human health: a clinical perspective. Postgraduate Medical Journal, 80: 516-526.

Gilliland SE. 1990 Health and nutritional benefits from lactic acid bacteria. FEMS Microbiology Reviews, 87: 175-188.

Gobbetti M, Ferranti P, Smacchi E, Goffredi F, Addeo F. 2002. Production of angiotensin-I converting enzyme-inhibitory peptides in fermented milk started by Lactobacillus delbrueckii subsp. bulgaricus SS1 and Lactobacillus lactis subsp. cremoris FT4. Applied and Environmental Microbiology, 66: 3898-3904.

Ipek G, Juneja VK, Ahmedna M. 2006. Probiotics in food safety and human health. Taylor \& Francis Group, LLC. pp. 468.

Hernandez-Ledesma B, Davalos A, Bartolomé B, Amigo L. 2005. Preparation of antioxidant enzymatic hydrolysates from alactalbumin and b-lactoglobulin. Identification of active peptides by HPLC-MS/MS. The Journal of Agricultural and Food Chemistry, 53: 588 .

Jiménez AM, Murcia MA, Parras P, Martínez-Tomé M. 2008. On the importance of adequately choosing the ingredients of yoghurt and enriched milk for their antioxidant activity. The International Journal of Food Science \& Technology, 43(8): 1464-1473.
Juskiewicz M, Panfil-Kuncewicz H. 2003. Reduction of cholesterol content in milk with dairy thermophilic cultures application. Milchwissenschaft, 58: 370-373.

Gueimonde M, Delgado S, Mayo B, Ruas-Madiedo P, Margolles A, de los Reyes-Gavilan CG. 2004. Viability and diversity of probiotic Lactobacillus and Bifidobacterium populations included in commercial fermented milks. Food Research International, 37: 839-850.

Guizani N, Kasapis S, Al-Ruzeiki M. 2001. Microbial, chemical, and rheological properties of laban (cultured milk). The International Journal of Food Science \& Technology, 36: 199-205.

Pawar HA, D'Mello PM. 2011. Spectrophotometric estimation of total polysaccharides in Cassia tora gum. Journal of Applied Pharmaceutical Science, 1(03): 93-95.

Lilly DM, Stillwell RH. 1965. Probiotics: Growth promoting factors produced by microorganisms. Science, 147: 747-748.

Maclntyre I, Ralston M. 1954. Direct determination of serum cholesterol. The Biochemical Journal. 56, xliii.

Malbaša R, Vitas J, Lončar E, Grahovac J, Milanović S. 2014. Optimization of the antioxidant activity of kombucha fermented milk products. Czech Journal of Food Sciences, 32: 477-484.

Sonia M, Sherman PM. 2009. Probiotics in Pediatric Medicine. Humana Press. pp. 347. ISBN: 978-1-60327-288-9.

Miller GD, Jarvis JK, Mcbean LD. 2000. Handbook of Dairy Foods and Nutrition, second edition, Boca Raton, London, New York, Washington DC, CRC Press.

Monthon L, Juthawadee K, Panupong W, Sararat T. 2014. Cholesterol-Lowering Potentials of Lactic Acid Bacteria with potential Probiotic Properties. International Journal of Pharm Tech Research, 7(3): 464-470.

Najgebauer-Lejko D, Sady M. 2015. Estimation of the antioxidant activity of the commercially available fermented milks. Acta Scientiarum Polonorum Technologia Alimentaria, 14(4): 387396.

Donkor ON, Henriksson A, Vasiljevic T, Shah NP. 2007. Proteolytic activity of dairy lactic acid bacteria and probiotics as determinant of growth and in vitro angiotensin converting enzyme inhibitory activity in fermented milk. Le Lait, 87(1): 21-38.

Pihlanto A, Korhonen H. 2003. Bioactive peptides and proteins. Advances in Food and Nutrition Research, 47: 176-275.

Hassan P, Peh KK. 2014. Characterization and identification of lactobacillus acidophilus using biolog rapid identification system. International Journal of Pharmacy and Pharmaceutical Sciences, 6(1): 189-193.

Rasic JLi, Kurmann JA. 1978. Yoghurt-Scientific Grounds, Technology, Manufacture and Preparations, Technical Dairy Publishing House, Copenhagen. pp. 117.

Rasic JL, Vujicic IF, Skringer M, Vulic M. 1992. Assimilation of cholesterol by some culture of lactic acid bacteria and bifidobacteria. Biotechnology Letters, 14: 39-44.

Samet-Bali O, Ayadi MA, Attia H. 2012. Development of fermented milk "Laban" made from spontaneous fermented cow's milk. African Journal of Biotechnology, 11(7): 1829-1837.

Samet-Bali O, Ennouri M, Dhouib A, Attia H. 2012. Characterization of typical Tunisian fermented milk: Laban. African Journal of Microbiology Research, 6(9): 2169-2175.

Sarmadi BH, Ismail A. 2010. Antioxidative peptides from food proteins: A review. Peptides 31: 1949.

Schrezenmeir J, de Vrese M. 2001. Probiotics, prebiotics, and synbiotics-Approaching a definition. American Journal of Clinical Nutrition, 73 (Suppl.): 361S-364S.

Shah NP. 2000. Effects of milk-derived bioactives: An overview. British Journal of Nutrition, 84: S3-S10.

Shehab SH, Hasan AM. 1978. Agricultural Biochemistry (practical)1st Ed. Baghdad university. Baghdad. Iraq. p

Shetty K, Curtis OF, Levin RE, Witkowsky R, Ang W. 1995. Prevention of verification associated with in vitro shoot culture of cysteine sulfoxide, an insulin secretagogue, in diabetic rats. Experientia, 52: 115-120. 
Shihata A, Shah NP. 2000. Proteolytic profile of yoghurt and probiotic bacteria. International Dairy Journal, 10: 401-408.

Shinmoto H, Dosako S, Nakajima. 1992. Antioxidant activity of bovine lactoferrin on iron/ascorbate induced lipid peroxidation. Bioscience, Biotechnology, and Biochemistry, 56: 2079.

Tantaoui-Elaraki A, Berrada M, El Marrakchi A, Berramou A. 1983. Etude sur le Lben marocain. Lait, 63: 230-245.

Tamime A. 2005. Probiotic dairy products. UK. Blackwell Publishing Ltd. p. 234.

Unal GEL. SN, Akalin AS, Dinkc N. 2013. Antioxidant activity of probiotic yoghurt fortified with milk protein-based ingredients. Italian Journal of Food Science, 25: 3-4.

Walstra P, Jenness R. 1984. Dairy Chemistry and Physics. John Wiley and Sons, Inc., New York.

Weaver CM, Daniel JR. 2005. The Food Chemistry Laboratory A Manual for Experimental Foods, Dietetics, and Food Scientists. Taylor \& Francis e-Library, pp. 150.

William CF, Dennis CW. 2011. Food Microbiology, Fourth edition, McGraw Hill, India, pp. 330.
Wohlrab Y, Bockelmann W. 1992. Purification and characterization of a dipeptidase from Lactobacillus delbrueckii subsp. bulgaricus. International Dairy Journal, 2: 345-361.

Yangilar F, Çakmakci S. 2017. Probiotic shelf-life, mineral contents, and other properties of probiotic yogurts supplemented with corn flour. Tar $1 \mathrm{~m}$ Bi 1 imleri Dergisi Tarım Bilimleri Dergisi- Journal of Agricultural Sciences, 23: 472-481.

Zak B, Dickenman RC, White EG, Burnett H, Cherney PJ. 1954. Rapid estimation of free and total cholesterol. American Journal of Clinical Pathology, 24: 1307.

Ziarno M, Sekul E, Lafraya AA. 2007. Cholesterol assimilation by commercial yoghurt starter cultures. Acta Scientiarum Polonorum Technologia Alimentaria, 6(1): 83-94.

Zlatkis A, Zak B, Boyle AJ. 1953. A new method for the direct determination of serum cholesterol. The Journal of Laboratory and Clinical Medicine, 41: 486.

Zulueta A, Maurizi A, Frígola A, Esteve MJ, Coli R, Burini G. 2009. Antioxidant capacity of cow milk, whey, and deproteinized milk. International Dairy Journal, 19(6): 380-385 